\title{
Study on Impact Strength Against Welding Smaw on Hardening Steel AISI 1050
}

\author{
Zulmiardi \\ Mechanical Engineering Department, Malikussaleh University, Lhokseumawe \\ Indonesia \\ Meriatna \\ Chemical Engineering Department, Malikussaleh University, Lhokseumawe, \\ Indonesia
}

\begin{abstract}
Results - From a hardening test, we then tested with an impact tester charpy Treviolo H060. The results showed that the impact strength is escalated up to $29.09 \%$ post-hardening circle, which was observed using electrical microscope. The value of steel strength increased $2.12 \mathrm{~J} / \mathrm{mm}^{2}$ compared with earlier hardening process, which is, $1.57 \mathrm{~J} / \mathrm{mm}^{2}$. The results showed that the fracture in the welding process without the hardening process is a brittle fracture that is shown by the flat crystal structure; on the other hand, the hardening process before welding shows a form of coarse-looking structure indicating that the specimen has an impact towards which the toughness is higher.

Research Limitations/Implications - The effect influence of the hardening process to the impact strength of welded joints before and after the hardening process SMAW AISI 1050 steel hardening process. The mechanical properties test is done with the equipment impact charpy.

Practical Implications - The field we often encounter is erosion or wear out occurring in the construction, for example, many equipments such as agricultural equipment, bridges, ship construction, motor shaft, machining such as hand tools, small rings, and agricultural tools.
\end{abstract}

Originality/Value - This is the first reported research on impact strength using the hardening test.

Keywords Steel AISI 1050, Electrode E7016, impact strength, Welding, hardening, electrical microscope

All papers within this proceedings volume have been peer reviewed by the scientific committee of the Malikussaleh International Conference on Multidisciplinary Studies (MICoMS 2017).

\section{Introduction}

Farid (2005) gives the effect of hardening and tempering on SMAW ASTM A533 steel welding and results are intended to determine the effect of variation in time on the treatment of weld toughness and to know changes in mechanical properties on the plate steel after welding and treatment. ASTM A533 (ASTM E23, 2007, Standard Test Method for Notched Bar Impact

(C) Zulmiardi, Meriatna. Published in the Emerald Reach Proceedings Series. Published by Emerald Publishing Limited. This article is published under the Creative Commons Attribution (CC BY 4.0) licence. Anyone may reproduce, distribute, translate and create derivative works of this article (for both commercial and non-commercial purposes), subject to full attribution to the original publication and authors. The full terms of this licence may be seen at http://creativecommons.org/licences/by/4.0/ legalcode

$-$

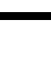


Proceedings of MICoMS 2017

\section{0}

Figure 1.

Shape and

Dimensions of the ASTM E23 Standard Impact Test Specimen
Testing of Metallic Materials, 2007) steel plate has a thickness of $12 \mathrm{~mm}$, a width of $75 \mathrm{~mm}$, and $300 \mathrm{~mm}$ long after welded; there are plates that can undergo heat treatment and some not; the heat treatment is done by hardening and tempering with variations in the holding time of 1,2 , and $3 \mathrm{~h}$. The tests are hardness test, impact test, and structure micro; the test is carried out in the parent area, the HAZ area, and the weld area both on the steel plate given heat treatment or not. The result of violent testing obtained by pricing of maximum violence occurs in $\mathrm{HAZ}$ areas that have gone through hardening processes, while the price of minimum fracture occurs in the weld area that has been through the tempering process with a hold time of $3 \mathrm{~h}$. Results: the impact test obtained at the maximum price occurs on the parent metal and the minimum impact price occurs during hardening process without tempering process (Widya Mukti, 2007). Microstructure found in steel ASTM A533 is ferrite, perlite, and marten site.

Nizam (2016) conducted research of toughness of impact weld on steel St 60 stelah, and found the impact of weld toughness to be highest at $275 \mathrm{~J} / \mathrm{mm}$ with a value of $2.61 \mathrm{~J} / \mathrm{mm}^{2}$ and lowest on the heat input $175 \mathrm{~J} / \mathrm{mm}$ with a value of $0.85 \mathrm{~J} / \mathrm{mm}^{2}$. The microstructure test results of the Las region decompose into three types: grain boundary ferrite, widmanstatten ferrite, and acicular ferrite. Grain boundary ferrite spreads evenly on the weld area, and its structure has a tenacious nature. In the parent metal, phase ferrite is more perlite which is spread out evenly. While in the Haz area, the growth of marten site occurs (Suparman, 2006). This matter shows that steel St 60 welding process experienced an increase in the violence in the Haz area along with higher heat input and cooling rate. AISI 1050 steel are widely used in various industries.

\section{Materials and methods}

Material AISI 1050 steel in the form of a plate with a length of $150 \mathrm{~mm}$, a width of $75 \mathrm{~mm}$, and a thickness of $10 \mathrm{~mm}$. Figure 1 shows Shape and Dimensions of the ASTM E23 Standard Impact Test Specimen.

For the formation of the corner of the veld, prior to the process of welding, the material was first made of welding groove, the veld used in this study was a single V-joint with an angle of 60(and a gap of $3 \mathrm{~mm}$. After the type of welding used in this research, is the process of welding Shielded Metal Arc Welding (SMAW) by using E7016 electrode at 100 A current. Before the impact test, the material first formed according to the needs of the impact test machine. Flatten groove welding using frais machine. For more details, we show in Figures 1 and 2 the shape and dimensions of the ASTM E23 standard impact test specimen.

The hardening process is using a heating oven to heat the test specimen to $830(\mathrm{C}$, with a holding time of until $15 \mathrm{~min}$ (Prayitno, 1999), for quenching water was used after hardening, and Charpy impact machine was used continuously for impact testing, as shown in Figure 2.

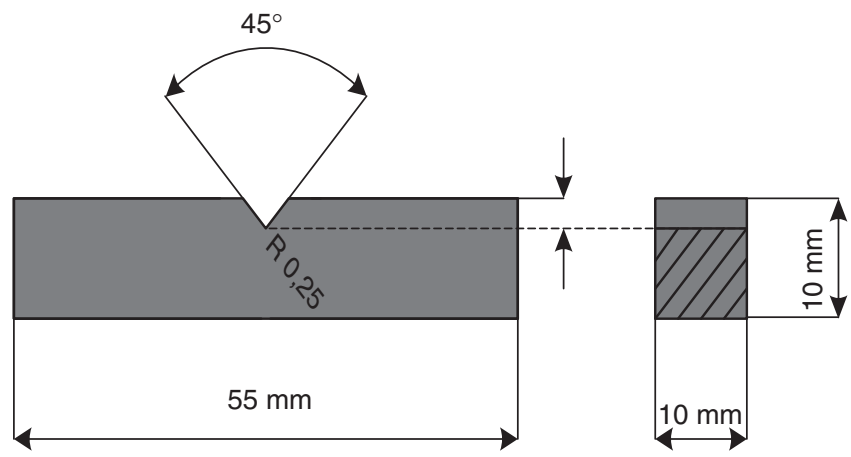




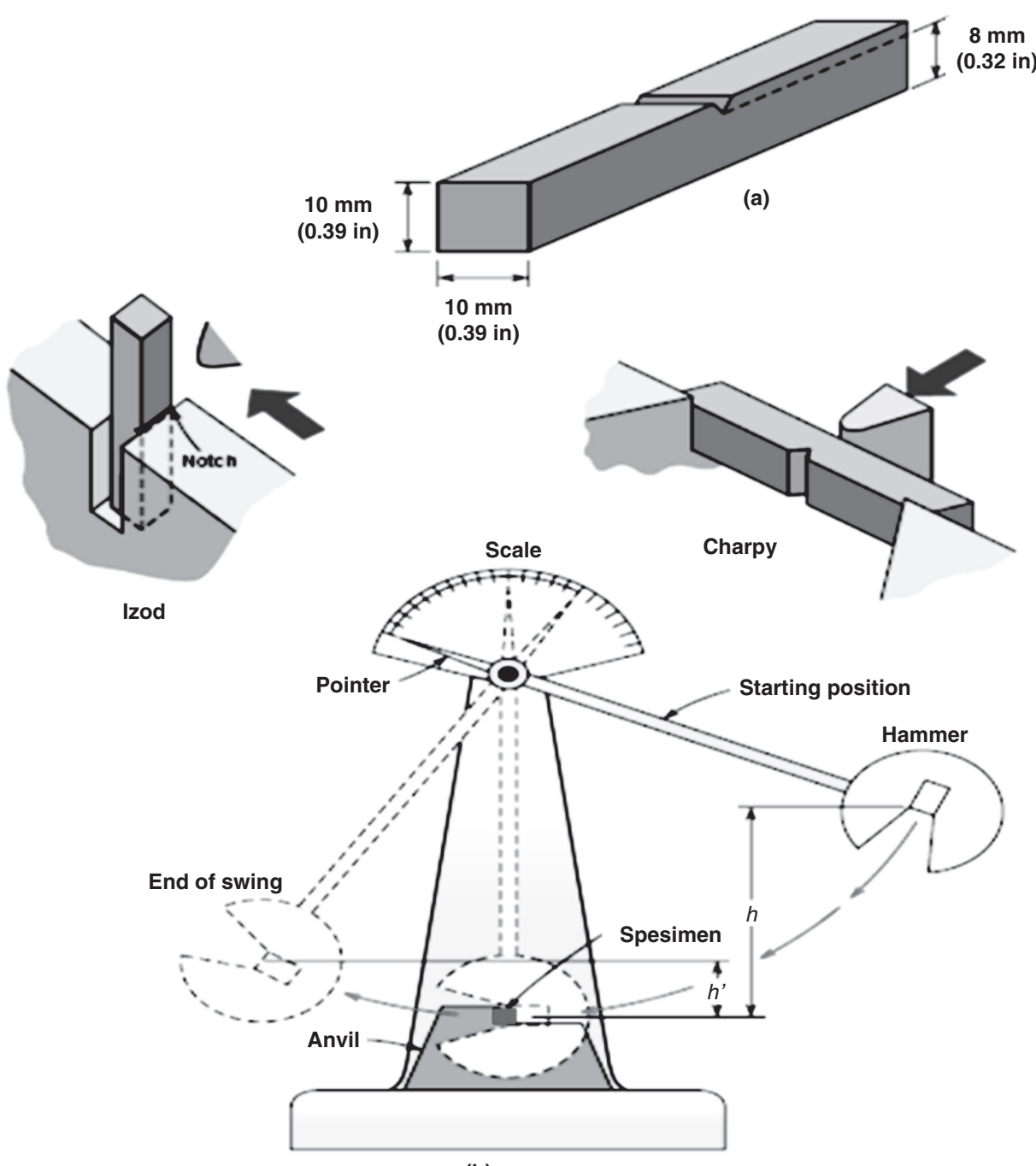

Study on Impact Strength

(b)

Figure 2. (a) Specimen used to Impact Test. (b) Set Up of Impact Charpy Treviolo H060 (Callister, 2007)

\section{Results and discussion}

Impact test was conducted to know the mechanical properties of medium carbon steel material as a test material in this research. The result of the impact test is generally the toughness parameter (notch blow value). The impact price can be calculated by the following equation:

$$
\text { Essor }=m g R(\cos \beta-\cos \alpha)
$$

where $m$ is the weight of the pendulum $(\mathrm{kg})=20 \mathrm{~kg} ; g$ is the gravitational acceleration $\left(\mathrm{m} / \mathrm{s}^{2}\right)$ $=9.8 \mathrm{~m} / \mathrm{s}^{2} ; R$ is the arm length $(\mathrm{m})=0.775 \mathrm{~m} ; \alpha$ is the pendulum angle before swung $=1400$; 
Proceedings of and $\beta$ is the angle of the pendulum swing after breaking the specimen, angle at the end of MICoMS 2017 each specimen.

$\begin{aligned} & \text { Essor }=m g R(\cos \beta-\cos \alpha) \\ & 262= 20 \mathrm{~kg} \times 9.8 \mathrm{~m} / \mathrm{s}^{2} \times 0.775 \mathrm{~m}(\cos 780-\cos 1400) \\ &= 20 \mathrm{~kg} \times 9.8 \mathrm{~m} / \mathrm{s}^{2} \times 0.775 \mathrm{~m}(0.207-(-0.766) \\ &= 20 \mathrm{~kg} \times 9.8 \mathrm{~m} / \mathrm{s}^{2} \times 0.775 \mathrm{~m}(0.973) \\ &= 147.80 \mathrm{~J} \\ & \text { Impact prices can be calculated by the following equation: }\end{aligned}$

$$
\mathrm{HI}=\operatorname{Esrp} / A^{0}
$$

where $\mathrm{HI}$ is the impact price $\left(\mathrm{J} / \mathrm{mm}^{2}\right)$; Esrp is the absorptive energy (J); and $A^{0}$ is the sectional area (height below notch $\times$ width specimen) $=80 \mathrm{~mm}^{2}$

$$
\begin{aligned}
\mathrm{HI} & =\frac{\text { Esrp }}{A^{0}}=(147.80 \mathrm{~J}) /\left(80 \mathrm{~mm}^{2}\right) \\
& =1.84 \mathrm{~J} / \mathrm{mm}^{2}
\end{aligned}
$$

The value of the results of the impact test is shown in Figure 3.

In Figure 3, the strength score graph shows that the mean impact strength on hardening specimens is $2.12 \mathrm{~J} / \mathrm{mm}^{2}$ with an absorbed energy of $170.65 \mathrm{~J}$. While the mean value of impact strength on welding specimen without hardening process is $1.57 \mathrm{~J} / \mathrm{mm}^{2}$ with an absorbed energy of $126.33 \mathrm{~J}$. The impact strength value of the hardening welding specimen is increased by $25.94 \%$ against the impact strength of the welding specimen without the hardening process, which is due to the heating process carried out on the AISI 1050 steel at $83^{\circ} \mathrm{C}$ for 15 min which can increase the toughness of the welds of the steel. The cross-section of the impact toughness test (Irvan, 2010). The specimen after being subjected to the test at the notch will be broken on the critical cross-section already specified; this section of the fault will be observed. Correct cross-section of the notch test can be seen differently, each fracture has different characteristics; generally, fracture form at the test of notch has three forms, namely brittle/brittle fracture, ductile fracture, and mixture fracture. For more details, we can see in Figures 4 and 5.

Figure 3.

Graph of Impact Strength Value Without Hardening Process and With Hardening Process

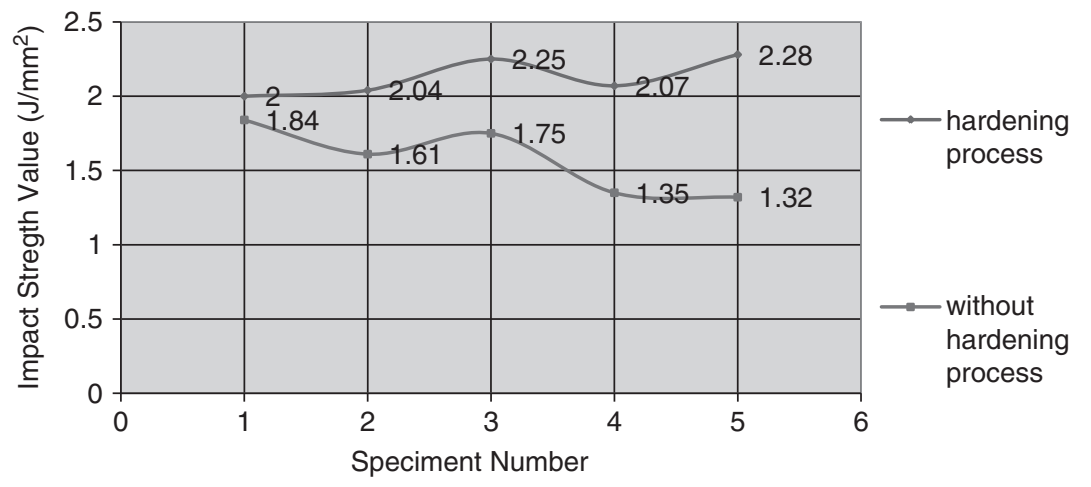




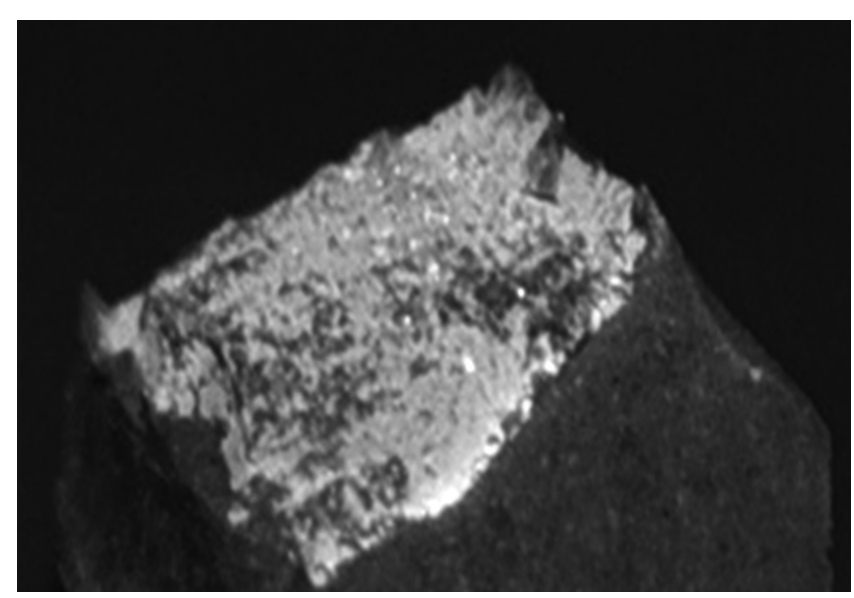

Study on

Impact

Strength

263

Figure 4.

Fracture Form on

Welded Specimen

Without Hardening

Process (Marrow, 2009)

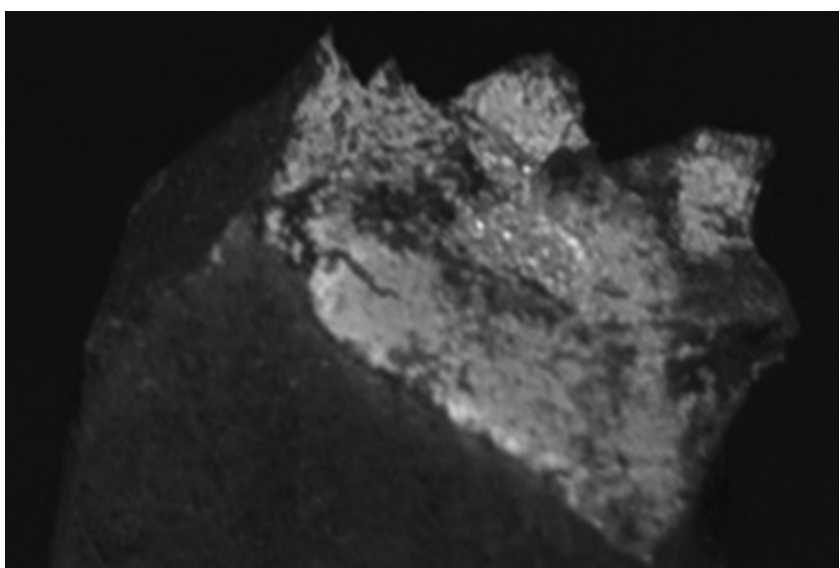

Figure 5.

Form on Welded Specimen With

Hardening Process (Marrow, 2009)

From the observation of the impact fracture in Figures 4 and 5, the fracture occurring on both specimens is very different. Figure 4 shows that the fracture pattern formed is a brittle fracture in which the crystal structure looks more flat, while Figure 5 shows a tenacious fracture in which the crystal form looks coarse and uneven, this indicates that this specimen has higher impact toughness.

\section{Conclusion}

The value of absorbent energy and impact toughness on welding specimens without the hardening process has a lower value than the welded specimen by the hardening process. The average value of energy absorbed is $126.33 \mathrm{~J}$ while the average value of its toughness is $1.57 \mathrm{~J} / \mathrm{mm}^{2}$.

The value of absorbent energy and impact toughness on welded specimens by hardening process has a higher value than welded specimens without the hardening process. The 
Proceedings of MICoMS 2017 average value of absorbed energy is $170.65 \mathrm{~J}$ and its toughness value is $2.12 \mathrm{~J} / \mathrm{mm}^{2}$, the value increases by $25.94 \%$ against the impact strength of the welding specimen without the hardening process.

The results of observation of the fracture in the welding specimen without the hardening process showed that the fracture pattern is formed in the form of a brittle fracture where the crystal structure is noticeably flatter than the hardening (Farid, 2005) specimen.

fracture where the crystal form looks coarse and uneven, indicating that this specimen has higher impact toughness.

For better welding results, welding is done in a vacuum and no contamination should occur during welding process; numerical reading on impact test results should be manual equipment (Amstead, 1989) but accurate, using different electrodes for impact testing, using AISI 1050 steel material for hardening material with quenching water medium to compare its impact strength, and the fracture that occurs is a single fracture/brittle fracture (Amanto, 1999)

\section{References}

Amanto, H. (1999). Ilmu Bahan Jakarta. Bumi Aksara, Jakarta.

Amstead, B. (1989). Teknologi Mekanik (Vol. 1). Erlangga, Jakarta.

ASTM E23. (2007). Standard Test Method for Notched Bar Impact Testing of Metallic Materials. American Society of Testing and Materials, New York.

Callister, William D. (2007). Material Science and Engineering: An Introduction. 7th Edition. John Wiley $\&$ Sons, Inc. New York.

Farid, I. (2005). Hardening dan Tempering Pada Hasil Pengelasan SMAW Terhadap Ketangguhan Las dan Sifat Mekanis. Teknik Mesin STTNAS, Yogyakarta.

Irvan, T. (2010). Analisa Ketangguhan dan Kekerasan Hasil Lasan Dengan Menggunakan Elektroda E7016 dan E6010. Teknik Mesin UNIMAL.

Marrow, J. (2009). Materials Science Internet Microscope. UMIST and University of Manchester, England. Available: www.umist.ac.uk/matsci.

Nizam, E. (2016). Pengaruh Heat Input Terhadap Ketangguhan Impac Las SMAW Posisi Vertikal Baja ST 60 Temper. Department of Mechanical Engineering, STTNAS, Yogyakarta.

Prayitno, A. (1999). "Pengaruh Perbedaan Waktu Penahanan Suhu Stabil Holding Time Terhadap Kekerasan Logam”. Jurnal Natur Indonesia, Vol. 1, No. 1, pp. 12-17.

Suparman. (2006). Pengaruh Suhu Annealing Pada Post Weld Heat Treatment Pengelasan Baja Bohler Grade K-945 EMS 45 Terhadap Sifat Fisis dan Mekanis. UNNS, Semarang.

Widya Mukti, S. (2007). Perubahan ketangguhan bahan st.40 yang telah Mengalami proses double hardening dengan Carburizing. UNNES, Semarang.

\section{Corresponding author}

Zulmiardi can be contacted at zulmiardi@unimal.ac.id 